\title{
Influence of Vermicompost as the Source of Nitrogen in Various Combinations with Chemical Fertiliser on Winter Wheat Productivity
}

\author{
Sruti Karmakar ${ }^{1,2^{*}}$ and Deepak Kashyap ${ }^{1}$ \\ ${ }^{1}$ Department of Civil Engineering, Indian Institute of Technology Ropar, Nangal Road, Rupnagar, Punjab-140001, India \\ ${ }^{2}$ Department of Environmental Science, Asutosh College, 92 S.P. Mukherjee Road, Kolkata-700026, West Bengal, India
}

\begin{abstract}
There is rarely any study that deals with the application of vermicompost in combination with chemical fertiliser to study the growth and yield variables of wheat crop in the typical agro-climatic conditions of saline sandy agricultural land of tropical semi-arid climatic condition with vast fluctuations of temperature between summer and winter seasons. Hence, the current study has been planned with a broader objective of utilising the organic resources by preparing vermicompost and applying it as the partial substitute of chemical fertiliser to cultivate wheat in an eco-friendly manner in saline sandy agricultural land of the tropical semi-arid zone. For achieving the intended goal, an experiment was conducted in the field of 'Soil-Water-Plant Laboratory', Department of Civil Engineering, IIT Ropar, Punjab, India during the winter season (rabi) of 2018-19. In this experiment, Randomized Block Design (RBD) was followed, and four treatments were used, including T1: 100\% RD using chemical fertilisers, T2: 50\% RD using chemical fertilisers $+50 \%$ of nitrogen through vermicompost, T3:75\% RD using chemical fertilisers $+25 \%$ of nitrogen through vermicompost and $\mathrm{T} 4$ : control (without any additional nutrients). Each treatment was replicated nine times. Plot size was $4 \mathrm{~m} \times 6 \mathrm{~m}$, and row to row spacing was $0.2 \mathrm{~m}$. Following statistical analysis, it was found that treatment T2 (50\% RD using chemical fertilisers $+50 \%$ of nitrogen through vermicompost) showed the best results, which were reflected in different parameters such as number of effective tillers per plant, ear length, number of grains per ear, and test weight, grain yield and straw yield of the wheat crop in comparison to other treatments. In this case, an almost equal amount of nitrogen supply from both organic and inorganic sources is responsible for getting the best results.
\end{abstract}

Keywords: nutrient management; agriculture; soil fertility; crop yield

\section{INTRODUCTION}

Wheat (Triticum aestivum L.) has the highest importance among cereal crops, and it is widely cultivated as a food grain. From ancient times, wheat has been playing a significant role in the economy of several countries. Among different cereal foods, this crop has $30 \%$ contribution, and in the aspect of total food calories, it supplies almost $20 \%$ calories directly or indirectly in the human body (Lal, 2007). Thus, necessary measures are required to increase its production to ensure a sufficient food supply. Many factors control wheat productivity; among them, mineral nutrition, especially nitrogen, plays a significant role. According to Palaniappan and Annadurai (2018), chemical fertilisers supply nutrients to the crop easily within a short period. Although the crop plants quickly utilise some parts of their elemental constituents, the remaining parts are either lost or unavailable to the plants resulting in passing through different chemical or biochemical reactions in the soil. Injudicious use of chemical fertilisers leads to environmental pollution and health problems (Savci, 2012). Hence, nutrient management is a vital stage in crop production. Organic manures can promote nutrients supply to the plant, improve its productivity, and maintain soil 
health (Zaller \& Kopke, 2004; Nouraein et al., 2020). According to Suthar (2008), among different manures, vermicompost provides a crucial source of different nutrients when it is applied in appropriate ratios with mineral fertilisers. Aira et al. (2002) reported that earthworms and microorganisms jointly convert organic materials into manure in the vermicomposting process. Bajsa et al. (2004) reported that vermicomposting is an easy and efficient compost preparation technique that can maintain a higher nutrient status in composted materials. Many scientists have worked on organic and inorganic fertiliser and their applications in agriculture. Chaudhry et al. (2017) has evaluated the effects of the recommended dose of fertiliser (RDF), vermicompost, Azotobacter, and phosphate-solubilising bacteria (PSB). In the 2-year study, they have found that the treatments with RDF combined with vermicompost at $5 \mathrm{t}$. ha-1 mixed with Azotobacter and PSB has increased the grain yield by $21.5 \%$, while a combination of RDF and compost at $10 \mathrm{t}$. $\mathrm{ha}^{-1}$ mixed with Azotobacter and PSB has an increment of $20.1 \%$, over the yield by the RDF treatment alone. From their study, Devi et al. (2011) reported that the application of $100 \%$ RDF (i.e., 120: 26.4: $50 \mathrm{~N}: \mathrm{P}: \mathrm{K} \mathrm{kg} \mathrm{ha}^{-1}$ ) combined with the mixture of vermicompost at $1 \mathrm{t}$. ha-1 and phosphate solubilising bacteria (PSB) and another combination of $75 \%$ RDF with vermicompost at $1 \mathrm{t}$. ha-1 mixed with PSB showed higher yield components and yield of wheat compared to the other treatments. Hu et al. (2016) arranged an experiment on the wheat crop with six treatments, such as fertilisation with nitrogen $(\mathrm{N})$, phosphorus $(\mathrm{P})$, manure $(\mathrm{M}), \mathrm{NP}, \mathrm{NPM}$, and control (without fertilisation). From their experiment, they showed that the grain yield, fertiliser-contribution rate (FCR), and precipitation-use efficiency (PUE) with manure (M) increased annually at the rate of $89 \mathrm{~kg} \cdot \mathrm{ha}^{-1} \cdot \mathrm{y}^{-1}, 1.47 \mathrm{~kg}$. $\mathrm{kg}^{-1} \cdot \mathrm{y}^{-1}$, and $0.13 \mathrm{~kg} \cdot \mathrm{mm}^{-1} \cdot \mathrm{y}^{-1}$, respectively. In their field experiments, Laxminarayana et al. (2011) reported that combined use of nitrogen, phosphorus, and potassium and farmyard manure showed a higher yield (18.7 $\mathrm{Mg} \mathrm{ha}^{-1}$ ) of sweet potato significantly. They also revealed that the combined use of organic manures and balanced fertilisers and lime produces higher crop yields and increased soil fertility strength. Ali et al. (2020) arranged a 2-years experiment on bread wheat. They showed that vermicompost application resulted in the highest productivity among three organic manures (press mud, vermicompost, and farmyard manure). In their experiment, Chopra et al. (2016) remarked that among 27 treatments (consisted of organic manures, inorganic fertilisers and biofertilisers), the treatment consisted of poultry manure at 5 t. ha $^{-1}$ combined with $75 \%$ NPK mixed with dual inoculation of Azotobacter and PSB showed a significantly high yield of the wheat crop. Hafez et al. (2020) conducted an experiment on wheat crops and noticed that the highest grain yield and nutrient uptake were performed at $75 \%$ field capacity from the combined application of vermicompost and biochar.

Following the literature review, it is observed that some studies (Devi et. al., 2011; Hu et. al., 2016; Chopra et. al., 2016; Chaudhry et. al., 2017; Singh et. al., 2018; Hafez et al., 2020) were conducted to explore the winter wheat yield under the combinational treatment effects of vermicompost, chemical fertiliser and/or other supplements. It is well known that vermicompost provides a crucial source of different nutrients. Literature also indicates that vermicompost is beneficial in decreasing soil salinity and sodicity and consequently leads to increased wheat production by enhancing soil quality (Hafez et. al., 2020; Ding et al., 2021). Interestingly, rarely any study deals with vermicompost application in combination with chemical fertiliser to study the growth and yield variables of wheat crop in the typical agro-climatic conditions of saline sandy agricultural land of tropical semi-arid climatic condition with huge fluctuations of temperature between summer and winter seasons. Hence, the current study has been planned with a broader objective of utilising the organic resources by preparing vermicompost and applying it as the partial substitute of chemical fertiliser to cultivate wheat in an ecofriendly manner in saline sandy agricultural land of the tropical semi-arid zone. It also aimed to determine the optimum nutrient mixture.

\section{MATERIALS AND METHOD}

The experiment was carried out at the field of soil -water plant laboratory, Dept. of Civil Engineering, IIT Ropar, Punjab (latitude $30^{\circ} 57^{\prime} 52.17^{\prime \prime} \mathrm{N}$, longitude $76^{\circ} 28^{\prime} 50.12^{\prime \prime}$ E), India during the winter season (rabi) of 2018-19. The 
soil of the experimental field was sandy silt in texture, having $\mathrm{BD} 1.56$ g. $\mathrm{cc}^{-1}, \mathrm{pH} 8.5$, organic carbon $0.79 \%$, available nitrogen $251 \mathrm{~kg}$. ha-1, available phosphorus $19 \mathrm{~kg}$. $\mathrm{ha}^{-1}$ and available potassium $267 \mathrm{~kg}$. ha $\mathrm{ha}^{-1}$. Bulk density was measured by the method of Blake and Hartge (1986). Soil $\mathrm{pH}$ was determined with the help of Backman's $\mathrm{pH}$ meter. Soil organic carbon, available nitrogen, available phosphorus, and available potassium were estimated by Walkley and Black's rapid titration method, Kjeldahl method, Olsen's method, and Flame photometer method, respectively (Jackson, 1973).

The experimental site was a tropical semi-arid type and average rainfall ranging from $500 \mathrm{~mm}$ to $750 \mathrm{~mm}$. Considerable variations are observed in maximum and minimum temperatures during summer (about $46^{\circ} \mathrm{C}$ ) and winter season (about $4{ }^{\circ} \mathrm{C}$ ). Wheat variety PBW343 was chosen as a rabi crop, and it was sowed on the $3^{\text {rd }}$ week of November 2018. Randomized Block Design (RBD) was followed by 4 different nutritional treatments in this experiment, and each treatment was replicated nine times. Treatments were T1: 100\% RD using chemical fertilisers (i.e. $\mathrm{N}-120 \mathrm{Kg}$. ha' ${ }^{-1}, \mathrm{P}_{2} \mathrm{O}_{5^{-}} 60 \mathrm{Kg}$. ha-1, $\mathrm{K}_{2} \mathrm{O}-40 \mathrm{Kg}$. ha-1), T2: 50\% $\mathrm{RD}$ using chemical fertilisers (i.e. $\mathrm{N}-60 \mathrm{Kg}$. ha- ${ }^{-1} \mathrm{P}_{2} \mathrm{O}_{5^{-}} 30$ $\mathrm{Kg}$. ha-1, $\mathrm{K}_{2} \mathrm{O}-20 \mathrm{Kg}$. ha-1) blended with $50 \%$ of nitrogen through vermicompost, $\mathrm{T} 3: 75 \% \mathrm{RD}$ using chemical fertilisers (i.e. $\mathrm{N}-90 \mathrm{Kg}$. ha-1, $\mathrm{P}_{2} \mathrm{O}_{5^{-}} 45 \mathrm{Kg}$. ha' $\mathrm{ha}^{-1} \mathrm{O}-30 \mathrm{Kg}$. $\mathrm{ha}^{-1}$ ) mixed with $25 \%$ of nitrogen through vermicompost and T4: control (without any additional nutrients). Plot size was $4 \mathrm{~m} \times 6 \mathrm{~m}$, row to row spacing was $0.2 \mathrm{~m}$, and plant to plant spacing was $0.1 \mathrm{~m}$. For this experiment, vermicompost was prepared in a tank (Palaniappan and Annadurai, 2018) and used for various treatments. Organic carbon (11.8\%), total nitrogen (1.22\%), total $\mathrm{P}_{2} \mathrm{O}_{5}(2.07 \%)$, and total $\mathrm{K}_{2} \mathrm{O}$ (0.79\%) had been predetermined were present in applied vermicompost.

In crop study, growth parameters (plant height, dry matter accumulation, leaf area index), yield attributes (number of effective tillers plant $^{-1}$, ear length, number of grains ear-1, and test weight), and yield (grain yield and straw yield) were recorded at the time of harvest. Statistical analysis of the collected data was performed using SPSS V.25.o (IBM, USA) software to establish the most suitable treatment. Moreover, the Pearson correlation coefficients were calculated for a few variables (number of effective tillers per plant, LAI, ear length, grain per ear, grain yield, and straw yield) to evaluate the degree of association between two selected variables for each treatment.

\section{RESULT AND DISCUSSION}

Different doses of fertiliser and organic manure (vermicompost) remarkably influenced the growth, yield attributes, and yield of the wheat crop in this present research. Figure 1 and Figure 2 show the descriptive statistics of all variables. For checking the applicability of parametric statistical tests, various assumptions were checked for the data set using the IBM SPSS software.

These included (1) test of normality - using the ShapiroWilk method (2) test of homogeneity of variances, and (3) test for non-multicollinearity using Spearman correlation coefficient.

These test results were found to be good enough to proceed with a parametric test like ANOVA. Results of oneway ANOVA results (Table-1) showed that there were significant differences among the nutritional treatments ( $\mathrm{T} 1$, $\mathrm{T}_{2}, \mathrm{~T}_{3}$, and $\mathrm{T}_{4}$ ) in the case of all variables except the Leaf Area Index (LAI). To understand the impact of different treatments on each variable, a Post-hoc test using Bonferroni multiple comparisons (Table 2) was conducted.

Table 1. Results of one-way ANOVA to study the difference in the measure of variables across the nutritional treatments

\begin{tabular}{lll}
\hline Sl. & Variables & F value \\
No. & & \\
\hline 1 & Plant height $\left[10^{-2} \mathrm{~m}\right]$ & $27.51^{*}$ \\
2 & DMA $\left[10^{-3} \mathrm{~kg} / \mathrm{m}\right.$ row length $]$ & $29.26^{*}$ \\
3 & Leaf area index & 1.87 \\
4 & No. of effective tillers per plant & $19.79^{*}$ \\
5 & Ear length $\left[10^{-2} \mathrm{~m}\right]$ & $7.97^{*}$ \\
6 & Grain per ear & $57.4^{*}$ \\
7 & Test weight $\left[10^{-3} \mathrm{~kg}\right]$ & $36.17^{*}$ \\
8 & Grain yield $\left[\mathrm{kg} / 10^{2} \mathrm{~m}^{2}\right]$ & $90.24^{*}$ \\
9 & Straw yield $\left[\mathrm{kg} / 10^{2} \mathrm{~m}^{2}\right]$ & $105.62^{*}$ \\
10 & Harvest Index $[\%]$ & $8.21^{*}$
\end{tabular}

${ }^{*}$ Significant at the $\mathrm{p} \leq 0.05$ level 
In Figure 1, treatment $\mathrm{T}_{3}$ has indicated maximum plant make the plant taller. It was also observed that dry matter height followed by treatments $\mathrm{T} 1$ and $\mathrm{T} 2$, whereas $\mathrm{T} 4$ accumulation was highest in treatment $\mathrm{T}_{3}$, followed by showed minimum plant height. Results of the post-hoc test treatments $\mathrm{T} 1$ and T2. Treatment T4 showed the lowest (Table 2) indicated that the mean difference of plant height value in dry matter accumulation, as there were no in T3 was significantly $(\mathrm{p} \leq 0.05)$ higher in comparison to chemical/ organic fertilisers. The result of the post-hoc test other treatments (T1, T2, and T4). According to Borse et al. revealed that the mean difference of dry matter (2019), plant height is influenced by the combined accumulation was significantly (p $\leq 0.05$ ) higher in the case application of chemical fertiliser and organic manure. This of $\mathrm{T}_{3}$ in comparison to all other treatments, but the mean combination increases the size of a plant cell. As a result, the difference was not significant (p>0.05) between T2 and T1 leaf area and photosynthesis rate rise. These ultimately (Table 2).
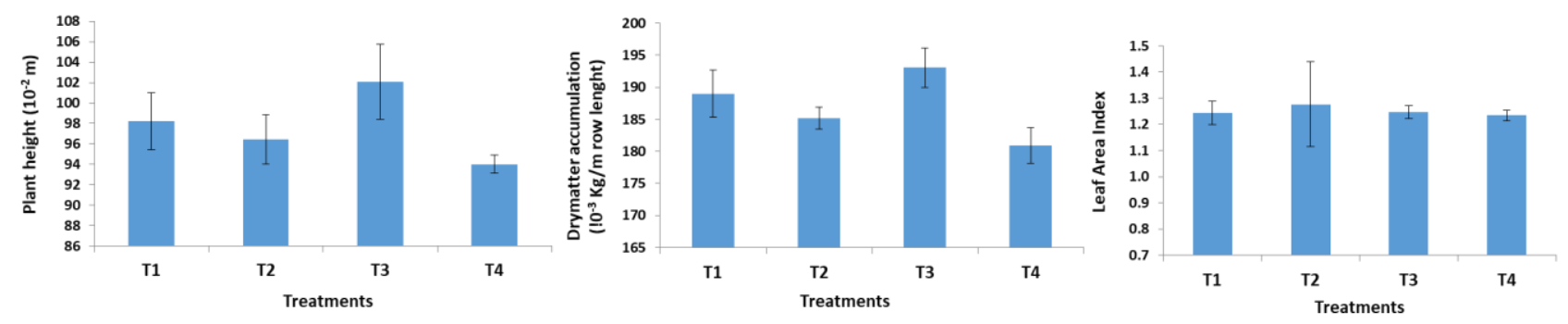

Figure 1. Comparisons of growth-related variables under different treatments

Table 2. Comparison between two different nutritional treatments for each of the variables under study

\begin{tabular}{|c|c|c|c|c|c|c|c|c|c|c|}
\hline \multirow[b]{2}{*}{ 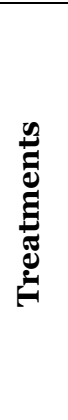 } & \multicolumn{10}{|c|}{ Mean Difference } \\
\hline & 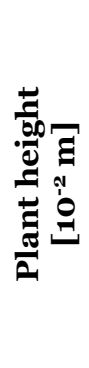 & 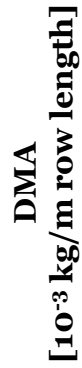 & 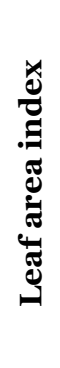 & 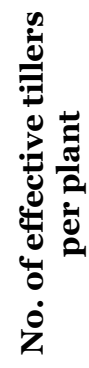 & 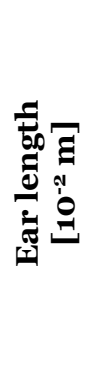 & 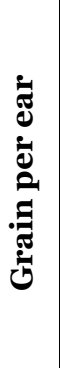 & 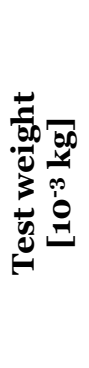 & 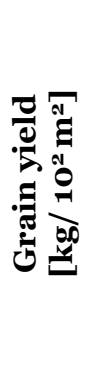 & 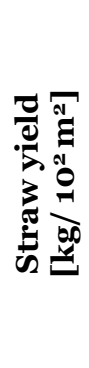 & 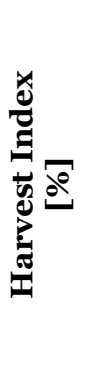 \\
\hline$\stackrel{F}{F}$ & $\begin{array}{l}\text { Nv } \\
\text { ô } \\
\dot{T}\end{array}$ & $\begin{array}{l}* \\
\infty \\
0 \\
\infty \\
1 \\
1\end{array}$ & $\begin{array}{l}0 \\
\stackrel{1}{0} \\
\stackrel{0}{0}\end{array}$ & $\begin{array}{l}* \\
\infty \\
\infty \\
i \\
i\end{array}$ & $\begin{array}{l}\text { N̦ } \\
\text { ì }\end{array}$ & 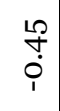 & $\begin{array}{l}\infty \\
\rightarrow \\
\rightarrow\end{array}$ & $\begin{array}{l}\stackrel{*}{A} \\
\stackrel{+}{+}\end{array}$ & $\begin{array}{l}{ }^{*} \\
\dot{\sigma} \\
\dot{\varphi}\end{array}$ & $\begin{array}{l}\stackrel{*}{\sigma} \\
\underset{i}{i}\end{array}$ \\
\hline$\stackrel{\stackrel{N}{*}}{\stackrel{F}{F}}$ & $\underset{+}{\overrightarrow{7}}$ & 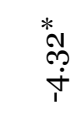 & $\begin{array}{l}\text { సે } \\
\text { î }\end{array}$ & 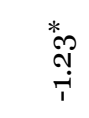 & $\begin{array}{l}\stackrel{*}{0} \\
\stackrel{+}{i} \\
i\end{array}$ & 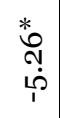 & $\begin{array}{l}\text { 苂 } \\
\text { ợ } \\
\text { oj }\end{array}$ & $\begin{array}{l}\text { * } \\
\stackrel{8}{0} \\
\stackrel{i}{i}\end{array}$ & $\begin{array}{l}* \\
\sigma \\
\dot{\sigma} \\
i\end{array}$ & $\begin{array}{l}\text { @o } \\
\stackrel{i}{i}\end{array}$ \\
\hline$\underset{f}{\stackrel{\infty}{*}}$ & $\begin{array}{l}\text { *ै } \\
\text { స̃ } \\
\text { }\end{array}$ & 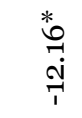 & به & 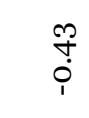 & 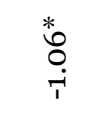 & $\begin{array}{l}\underbrace{*}_{0} \\
\stackrel{0}{+} \\
\dot{\varphi}\end{array}$ & $\begin{array}{l}\text { 苚 } \\
\text { 官 }\end{array}$ & 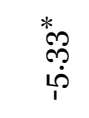 & $\begin{array}{l}\stackrel{*}{*} \\
\stackrel{*}{\oplus} \\
\stackrel{7}{1}\end{array}$ & $\begin{array}{l}\text { oे } \\
0\end{array}$ \\
\hline$\stackrel{N}{\stackrel{N}{*}}$ & $\begin{array}{l}\vec{b} \\
\stackrel{i}{ }\end{array}$ & $\underset{\dot{\infty}}{\hat{N}}$ & $\begin{array}{l}\text { ?} \\
\stackrel{0}{0}\end{array}$ & 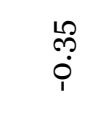 & సָ ָָ & \begin{tabular}{l}
$*$ \\
\multirow{2}{*}{} \\
$\infty$ \\
$\dot{T}$ \\
$\dot{T}$
\end{tabular} & 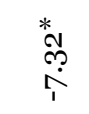 & $\begin{array}{l}\stackrel{*}{*} \\
\stackrel{p}{\sim} \\
\dot{\varphi}\end{array}$ & 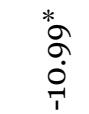 & $\stackrel{\hat{\kappa}}{0}$ \\
\hline$\stackrel{\infty}{\stackrel{\infty}{H}}$ & $\begin{array}{l}\text { *o } \\
\text { ồ } \\
\text { în }\end{array}$ & 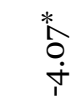 & $\begin{array}{l}a \\
0 \\
0\end{array}$ & $\begin{array}{l}+7 \\
0\end{array}$ & $\begin{array}{l}\text { No } \\
\text { ô } \\
1\end{array}$ & $\begin{array}{l}{ }^{*} \\
\dot{\varphi} \\
\dot{\varphi}\end{array}$ & $\begin{array}{l}* \\
\sigma \\
\dot{\rho} \\
\dot{\varphi}\end{array}$ & $\begin{array}{l}0 \\
\stackrel{0}{i} \\
i\end{array}$ & \begin{tabular}{l}
$*$ \\
\multirow{\infty}{0}{} \\
$\infty$ \\
$\infty$ \\
1
\end{tabular} & 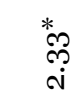 \\
\hline 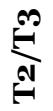 & $\begin{array}{l}\stackrel{*}{\infty} \\
\stackrel{\infty}{\hat{T}}\end{array}$ & 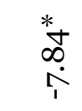 & ț & $\grave{\imath}$ & $\begin{array}{l}\stackrel{P}{+} \\
\dot{0}\end{array}$ & 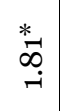 & 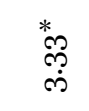 & $\begin{array}{l}\stackrel{*}{*} \\
\text { î } \\
\stackrel{+}{*}\end{array}$ & $\begin{array}{l}\text { : } \\
\stackrel{0}{0} \\
\stackrel{\sim}{*}\end{array}$ & : \\
\hline
\end{tabular}

* The mean difference is significant at the $\mathrm{p}<0.05$ level 
The high accumulation of dry matter in $\mathrm{T} 3$ followed by $\mathrm{T} 1$ could be due to the high growth of plants with higher levels of major nutrients, which resulted from the adequate food supply (Yesuf \& Balcha, 2014) due to the higher amount of chemical fertilisers $\left(75 \%\right.$ and $100 \%$ of RDF in the case of $\mathrm{T}_{3}$ and $\mathrm{T} 1$, respectively). In the case of LAI, treatment $\mathrm{T} 2$ showed maximum value, followed by treatments $\mathrm{T} 1, \mathrm{~T}_{3}$, and $\mathrm{T} 4$. The mean difference was not significant ( $\mathrm{p}>0.05$ ) among all treatments (Table 2). These results are in accordance with those observed by Diallo et al. (2019) and Yesuf and Balcha (2014). They noticed that the high rate of photosynthesis increased in plant dry matter, but it was not dependent on the fertiliser application.

In the case of effective tiller counting, treatment T2 showed the highest number of tillers per plant, followed by treatments $\mathrm{T}_{1}$ and $\mathrm{T}_{3}$. The lowest number of tillers was observed in the case of treatment $\mathrm{T}_{4}$ (Figure 2). Although the mean difference for the number of tillers per plant was not significant $(\mathrm{p}>0.05)$ between $\mathrm{T} 2$ and $\mathrm{T} 1$, significant ( $\mathrm{p} \leq 0.05)$ mean differences were observed for $\mathrm{T} 2 \mathrm{vs}$. $\mathrm{T} 4$ and T2 vs. T3 (Table 2). The proper nitrogen application resulted in the reduction of mortality of tillers and produced more tillers (Yesuf \& Balcha, 2014). Production of fertile tillers results in higher yield because the number of effective tillers is important in yield. According to $\mathrm{Hu}$ et al. (2016), they also reported that the use of a combined form of organic manure and chemical fertilisers improves soil quality. Thus, it can be postulated that the use of vermicompost mixed with chemical fertilisers played a role in generating more tillers per plant in the case of $\mathrm{T}_{2}$ and $\mathrm{T}_{3}$. The highest ear length was observed in treatment $\mathrm{T} 2$, followed by treatments $\mathrm{T}_{3}$ and T1. The lowest ear length was seen in treatment $\mathrm{T}_{4}$. From the result of the post-hoc test, it was found that the mean difference of ear length was significant $(\mathrm{p} \leq 0.05)$ for T2 vs. T1 and T2 vs. T4, but the mean difference was insignificant ( $\mathrm{p}>0.05$ ) between $\mathrm{T} 2$ and $\mathrm{T} 3$ (Table 2). This might be due to the positive impact of organic manure (vermicompost) on the supply of nutrients in the case of combinational application of chemical fertilisers and organic manure. These results are in agreement with the finding of Borse et al. (2019).
The value of grain per ear was maximum in treatment T2, followed by treatments $\mathrm{T}_{3}$ and $\mathrm{T} 1$ (Figure 2). The minimum value was observed for treatment $\mathrm{T}_{4}$. Table 2. depicted that the mean difference of grain per ear in T2 was significantly ( $\mathrm{p} \leq 0.05$ ) higher than other treatments ( $\mathrm{T} 1, \mathrm{~T}_{3}$, and $\mathrm{T}_{4}$ ). According to Chopra et al. (2016), nitrogen promotes the initiation of spikelets that resulted in more seeds per spike, but more nitrogen levels decreased the number of seeds due to increased vegetative growth. Nitrogen applied in optimum dose decrease the chance of seeds to deteriorate (Seiling et al., 2005). In this study, vermicompost as a source of nitrogen played a crucial role in producing more grain in each ear, as observed in the case of T3 and T2. Test weight was highest for treatment T2, followed by treatments $\mathrm{T}_{3}$, T1, and $\mathrm{T} 4$. The mean difference of test weight was significant $(\mathrm{p} \leq 0.05)$ between the two treatments except for $\mathrm{T} 1$ vs. $\mathrm{T}_{4}$ (Table 2). These results indicated the combined use of chemical fertilisers and vermicompost plays a crucial role in the maturity of grain. 

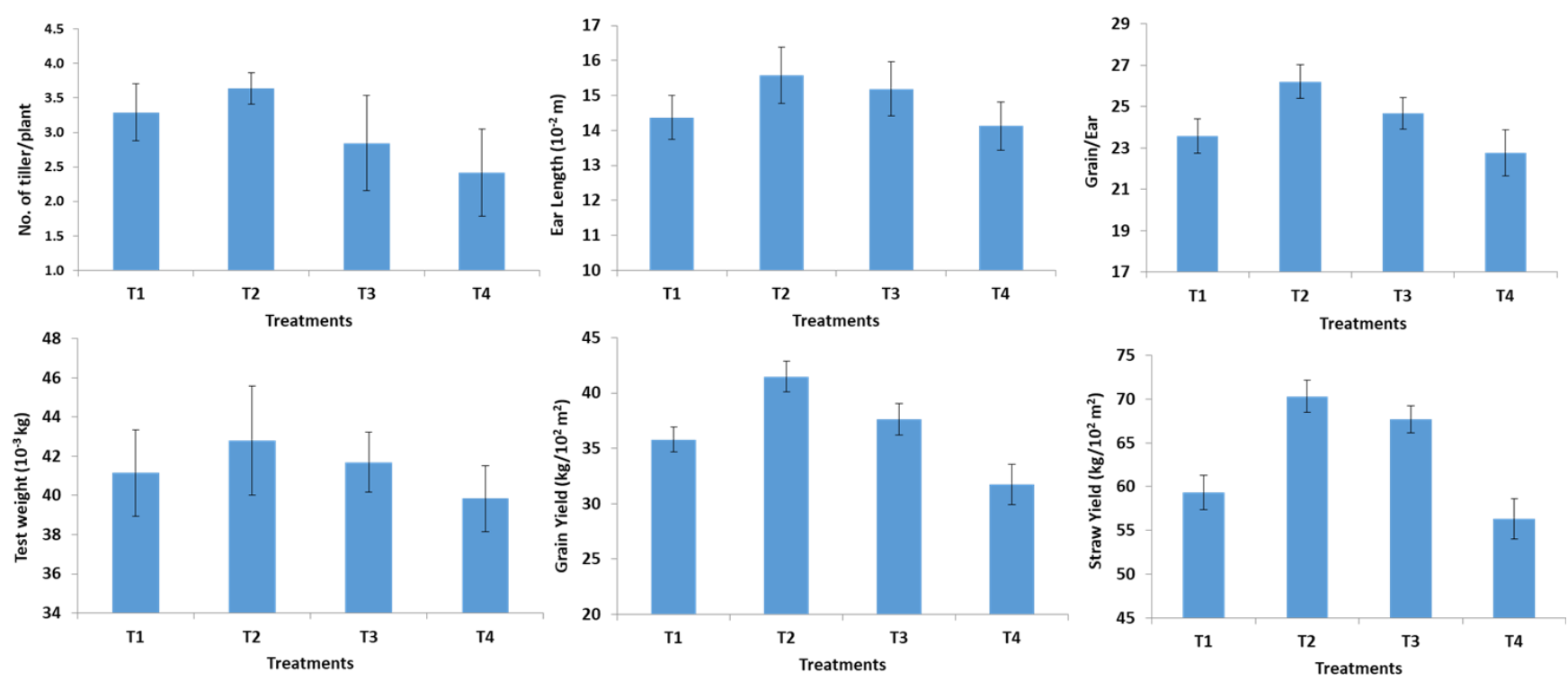

Figure 2. Comparisons of yield related variables under different treatments

Grain yield is the final reflection of all nutritional treatments through various developmental stages of the crop. The results of post-hoc test have shown that the maximum grain yield was obtained from treatment T2, followed by the treatments $\mathrm{T}_{3}, \mathrm{~T} 1$, and lastly, $\mathrm{T}_{4}$. The mean difference of grain yield in T2 was significantly $(\mathrm{p} \leq 0.05)$ higher in comparison to other treatments ( $\mathrm{T} 1, \mathrm{~T} 2$, and $\mathrm{T} 4$ ), and there was significantly $(\mathrm{p} \leq \mathrm{0.05})$ higher mean the difference among all treatments except T1 vs. T3 (Table 2). The highest straw yield was found by treatment $\mathrm{T} 2$, followed by the treatments $\mathrm{T}_{1}, \mathrm{~T}_{3}$, and $\mathrm{T}_{4}$, in that order. Lastly, the mean difference between each pair of treatments was significant ( $\mathrm{p} \leq 0.05)$. According to Suhane et al. (2008) and Ansari (2011), vermicompost is rich in nutrients, which increases crop yield. The result of the current research is in agreement with Karmegam and Daniel's (2000) findings. They mentioned that vermicompost has a vital role in improving the growth and yield of different crops. The present result is also supported by the findings of Patil and Sheelavantar (2000) and Palaniappan and Annadurai (2018). In their study, the application of vermicompost improved crop yield and quality. This might be due to the easy accessibility of nutrients and soil environment for better retention of nutrients and water due to organic manures and, finally, the effect on grain yield. The highest harvest index (\%) was observed in treatment $\mathrm{T} 1 \mathrm{HI}=37.84)$ followed by treatments $\mathrm{T} 2(\mathrm{HI}=37.14), \mathrm{T} 4(\mathrm{HI}=36.20)$, and $\mathrm{T}_{3}(\mathrm{HI}=35.52)$, but there was no significant ( $\mathrm{p}>0.05)$ difference in $\mathrm{T} 4 \mathrm{vs}$. T2, $\mathrm{T} 4$ vs. T3, and T2 vs. T1. Harvest index is directly related to the biological yield and grain yield, which ultimately depends upon the accessibility of nutrients, especially nitrogen. As the harvest index is the ratio of grain yield and biological yield (grain + straw yield), no clear trend can be perceived for various treatments. The treatment, which increased grain yield, also increased straw yield, and thus, the overall value of harvest index remained inconclusive. 
Table 3. Correlation between variables under different nutritional treatments (T1, T2, $\mathrm{T}_{3}$, and $\mathrm{T} 4$ )

\begin{tabular}{|c|c|c|c|c|c|c|c|}
\hline & & 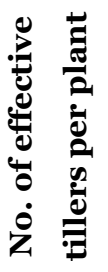 & & 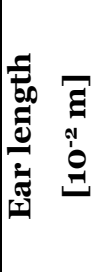 & 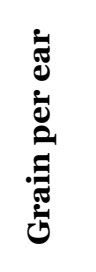 & 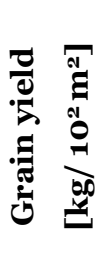 & 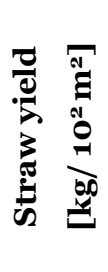 \\
\hline \multirow{4}{*}{$\begin{array}{c}\text { No. of effective } \\
\text { tillers per } \\
\text { plant }\end{array}$} & T1 & 1 & $-.795^{*}$ & -.150 & -.059 & -.479 & .387 \\
\hline & T2 & 1 & .225 & -.415 & -.058 & -.344 & .286 \\
\hline & T3 & 1 & -.263 & -.215 & -.072 & -.163 & .357 \\
\hline & T4 & 1 & .365 & .054 & -.081 & -.286 & -.543 \\
\hline \multirow{4}{*}{$\begin{array}{c}\text { Leaf area } \\
\text { index }\end{array}$} & T1 & $-.795^{*}$ & 1 & .207 & .161 & .081 & -.539 \\
\hline & T2 & .225 & 1 & -.020 & -.304 & .278 & .162 \\
\hline & T3 & -.263 & 1 & .065 & -.076 & .514 & -.142 \\
\hline & T4 & .365 & 1 & .145 & $-.680^{*}$ & .142 & -.552 \\
\hline \multirow{4}{*}{$\begin{array}{c}\text { Ear length } \\
{\left[10^{-2} \mathrm{~m}\right]}\end{array}$} & T1 & -.150 & .207 & 1 & .349 & -.381 & -.157 \\
\hline & T2 & -.415 & -.020 & 1 & .044 & .309 & -.542 \\
\hline & T3 & -.215 & .065 & 1 & .124 & -.395 & -.236 \\
\hline & T4 & .054 & .145 & 1 & -.187 & .345 & -.100 \\
\hline \multirow[t]{4}{*}{ Grain per ear } & $\mathbf{T 1}$ & -.059 & .161 & .349 & 1 & -.575 & .495 \\
\hline & T2 & -.058 & -.304 & .044 & 1 & -.206 & -.406 \\
\hline & T3 & -.072 & -.076 & .124 & 1 & .393 & -.595 \\
\hline & T4 & -.081 & $-.680^{*}$ & -.187 & 1 & -.224 & .060 \\
\hline \multirow{4}{*}{$\begin{array}{l}\text { Grain yield } \\
{\left[\mathrm{kg} / \mathrm{10}^{2} \mathrm{~m}^{2}\right]}\end{array}$} & T1 & -.479 & .081 & -.381 & -.575 & 1 & -.253 \\
\hline & T2 & -.344 & .278 & .309 & -.206 & 1 & -.532 \\
\hline & T3 & -.163 & .514 & -.395 & .393 & 1 & -.270 \\
\hline & T4 & -.286 & .142 & .345 & -.224 & 1 & .382 \\
\hline \multirow{4}{*}{$\begin{array}{l}\text { Straw yield } \\
{\left[\mathrm{kg} / \mathrm{10}^{2} \mathrm{~m}^{2}\right]}\end{array}$} & T1 & .387 & -.539 & -.157 & .495 & -.253 & 1 \\
\hline & T2 & .286 & .162 & -.542 & -.406 & -.532 & 1 \\
\hline & T3 & .357 & -.142 & -.236 & -.595 & -.270 & 1 \\
\hline & T4 & -.543 & -.552 & -.100 & .060 & .382 & 1 \\
\hline
\end{tabular}

${ }^{*}$ Significant at the $\mathrm{p} \leq 0.05$ level

Correlation study (Table 3) among few variables (number of effective tillers per plant, LAI, ear length, grain per ear, grain yield, and straw yield) for each of the treatments (T1, T2, T3, and T4) exhibited positive or negative correlations between the variables under study, but these were not statistically significant.

Significant negative were found only in two cases, including LAI vs. the number of effective tillers per plant in treatment T1 and LAI vs. Grain per ear in treatment T4. As the overall correlation coefficients were not statistically significant, observation of the correlation study was not helpful in explaining the phenomena of significant difference of the variables across various treatments. Kaur et al. (2017) observed that growth parameters are significantly correlated with vegetation indices at the booting stage of wheat. Thus, the overall observation from correlation statistics of current research is not corroborating with the finding of Kaur et al. (2017).

The experimental design of the current research was based on the RD of NPK (N- $120 \mathrm{Kg}$. ha-1, $\mathrm{P}_{2} \mathrm{O}_{5^{-}} 60 \mathrm{Kg}$. ha-1, $\mathrm{K}_{2} \mathrm{O}-$ $40 \mathrm{Kg}$. ha-1). It was focused on keeping the nitrogen supplement almost the same (about $120 \mathrm{~kg}$. ha-1) in various treatments where vermicompost was used to replace chemical fertilisers in specific proportions. It is true that the nitrogen content in the vermicompost and the actual availability of nitrogen from the applied vermicompost in 
field conditions are not the same. The availability of nitrogen from the vermicompost is influenced by various factors like the presence of microbes in the soil, its water content, etc. Hence, the addition of vermicompost will enhance a certain percentage of nitrogen to fulfil the amount of nitrogen as per the recommended dose might not always be correct. Besides, vermicompost contains nitrogen and other elemental nutrients essential for the plant's growth and yield. Another important limitation of the present research is the non-inclusion of $100 \%$ nitrogen supplement through vermicompost. Incorporation of this treatment and its comparison with other treatments under study would have revealed some valuable information.

\section{CONCLUSION}

Observations of the present experiment conclude that utilisation of vermicompost for partial substitution of chemical fertilisers does not only facilitate the test weight, grain per ear, ear length, etc. and thereby higher crop yield of wheat but also impart a positive impact on straw yield.
Different parameters such as number of effective tillers per plant, ear length, number of grains per ear, test weight, grain yield, and straw yield of the wheat crop were significantly higher when $50 \%$ of $\mathrm{RD}$ through chemical fertilisers and $50 \%$ of nitrogen through vermicompost were applied. Because in this treatment, an almost equal amount of nitrogen supply from both organic and inorganic sources helps to get a better result. This is due to the fact that the applied vermicompost supplied nitrogen and other major plant nutrients along with various micronutrients to the crop. Finally, it can be concluded that a mixture of organic and inorganic nutrients assists in improving soil fertility, which is reflected by the exceeding crop production if compared with the sole application of chemical fertilisers.

\section{ACKNOWLEDGEMENT}

The authors wish to thank Soil -Water - Plant laboratory, Department of Civil Engineering, Indian Institute of Technology Ropar for financial support.

\section{REFERENCES}

Aira, M, Monrot, F, Dorninguez, J \& Mato, S 2002, 'How earthworm density affects microbial biomass and activity in pig manure', European J. Soil Biol., vol. 38, pp. 7-10.

Ali, N, Khan, MN, Ashraf, MS, Ijaz, S, Rehman, HSu, Abdullah, M, Ahmad, N, Akram, HM \& Farooq, M 2020, 'Influence of different organic manures and their combinations on productivity and quality of Bread Wheat', J. Soil Sci. Plant Nutr., vol. 20, pp. 1949-196o.

Ansari, AA 2011, 'Worm powered environmental biotechnology in organic waste management', Int. J. Soil Sci., vol. 6, no. 1, pp. 25-30.

Bajsa, O, Nair, J, Mathew, K \& Ho, GE 2004, 'Vermiculture as a tool for domestic waste water management', Water Sci. Technol., vol. 48, pp. 125-132.

Blake, GR \& Hartge, KH 1986, 'Bulk density', ed Klute, A, In Methods of soil analysis, Part I, $2^{\text {nd }}$ edn, Physical and Mineralogical Methods: Agronomy Monograph, no. 9, pp. $363-375$.

Borse, DK, Usadadia, VP \& Thorave, DS 2019, 'Nutrient management in wheat (Triticum aestivum L.) under partially reclaimed coastal salt affected soil of south
Gujarat', Int. J. Curr. Microbiol. App. Sci, vol. 8, no. 5, pp. 1590-1599.

Chopra, R, Sharma, M, Sharma, SK, Nepalia, V, Jain, HK \& Singh, A 2016, 'Effect of integrated nutrient management on growth and yield of Wheat (Triticm Aestivum L.) in Haplustepts', Int J Sci Nat., vol. 7, no. 3, pp. 622-628.

Chaudhry, S, Khan, N, Singh, UP, Pyare, R, Singh, YK, Srivastav, AK, Verma, VK \& Chauhan, GV 2017, 'Effect of integrated nutrient management on productivity and economics of wheat (Triticum aestivum)', Indian J Agron, vol. 62, no. 4, pp. 476-48o.

Devi, KN, Singh, MS, Singh, NG \&Athokpam, S 2011, 'Effect of integrated nutrient management on growth and yield of wheat (TriticumaestivumL.)', J. Crop Weed, vol. 7, no. 2, pp. 23-27.

Diallo, F, Masse, D, Diarra, K \& Feder, F 2019, 'Impact of organic fertilisation on lettuce biomass production according to the cultivation duration in tropical soils', Acta Agr Scand B-S P, vol. 70, no. 3, pp. 215-223.

Ding Z, Kheir, AMS, Ali, OAM, Hafez, EM, ElShamey, EA, Zhou, Z, Wang, B, Lin, X, Ge, Y, Fahmy, AE \& Seleiman, 
MF 2021, 'A vermicompost and deep tillage system to improve saline-sodic soil quality and wheat productivity', J. Environ. Manage., vol. 277, pp. 111388.

Hafez, EM, Omara, AED, Alhumaydhi, FA \& El-Esawi AM 2020, 'Minimizing hazard impacts of soil salinity and water stress on wheat plants by soil application of vermicompost and biochar', Physiol Plant., vol. 172, pp. 587-602.

Hu, Y, Hao, M, Weia, X, Chen, X \& Zhaoa, J 2016, 'Contribution of fertilisation, precipitation, and variety to grain yield in winter wheat on the semi-arid Loess Plateau of China', Acta Agr Scand B-S P, vol. 66, no. 5, pp. 406-416. Jackson, ML 1973, Soil chemical analysis, $2^{\text {nd }}$ edn, New Delhi, Prentice Hall of India Ltd.

Karmegam, N \& Daniel, T 2000, 'Effect of biodigested slurry and vermicompost on the growth and yield of cowpea [Vigna unguiculata (L.)]', Environ. Ecol., vol. 18, no. 2, pp. 367-370.

Kaur, S, Singh, SP, Kingra, PK \& Ram, H 2017, 'Spectral response of wheat (Triticumaestivum L.) to varying nitrogen levels and their relationship with growth parameters', J Agrometeorol., vol. 19, pp. 187-191.

Lal, R 2007, 'Anthropogenic influences on world soils and implications to global food security', Adv. Agron., vol. 93, pp. 69-93.

Laxminarayana, K, John, KS, Ravindran, CS \& Naskar, SK 2011, 'Effect of lime, inorganic, and organic sources on soil fertility, yield, quality, and nutrient uptake of sweet potato in Alfisols', Commun Soil Sci Plant Anal., vol. 42, pp. 2515-2525.

Nouraein, M, Kouchak-khani, H, Janmohammadi, M, Mohamadzadeh, M \& Ion, V 2020, 'The effects of tillage and fertilizers on growth characteristics of kabuli chickpea under mediterranean conditions', Acta Technol. Agric., vol. 23, no. 1, pp.18-23.
Palaniappan, SP \& Annadurai, K 2018, Organic farming: Theory and Practice, Jodhpur, India, Scientific Publisers. Patil, SL \& Sheelavantar, MN 2000, 'Effect of moisture conservation practices, organic sources and nitrogen levels on yield, water use and root development of rabi sorghum [Sorghum bicolor (L.) Moench] in the vertisols of semiarid tropics', Annals of Agricultural Research, vol. 21, no. 1, pp. 32-36.

Savci, S 2012, 'An agricultural pollutant: chemical fertilizer', International Journal of Environmental Science and Development, vol. 3, no. 1, pp. 77-80.

Sieling, K, Stahl, C, Winkelmann, C \& Christen, O 2005, 'Growth and yield of winter wheat in the first 3 years of a monoculture under varying $\mathrm{N}$ fertilization in $\mathrm{NW}$ Germany', Eur. J. Agron., vol. 22, pp. 71-84.

Singh, G, Kumar, S, Sidhu, GS \& Kaur, R 2018, 'Effect of integrated nutrient management on yield of wheat (Triticum aestivum L.) under irrigated conditions', International Journal of Chemical Studies, vol. 6, no. 2, pp. 904-907.

Suhane, RK, Sinha, RK \& Singh, PK 2008, 'Vermicompost, cattle-dung compost and chemical fertilizers: impacts on yield of wheat crops', In Communication of Rajendra Agriculture University, Pusa, Bihar, India.

Suthar, S 2008, 'Bioremediation of aerobically treated distillery sludge mixed with cow dung by using an epigeic earthworm Eisenia fetida', The Environmentalist, vol. 28, pp. $76-84$.

Yesuf, E \& Balcha, A 2014, 'Effect of nitrogen application on grain yield and nitrogen efficiency of rice (Oryza sativa L.)', Asian J. Crop Sci., vol. 6, no. 3, pp. 273-28o.

Zaller, JG \& Kopke, U 2004, 'Effects of traditional and biodynamic farmyard manure amendment on yields, soil chemical, biochemical and biological properties in a long term field experiment', Biol Fert Soils, vol. 40, pp. 222229. 